UDC 656

\title{
The Analysis of Available Data on Energy Efficiency of Electric Vehicles to be Used for Eco-Driving Project Development
}

\author{
M. Maljković( ${ }^{1)}$, D. Stamenković( ${ }^{1)}$, I. Blagojević( ${ }^{1)}$, V. Popović ${ }^{1)}$ \\ ${ }^{1)}$ University of Belgrade (Belgrade, Republic of Serbia) \\ (C) Белорусский национальный технический университет, 2019 \\ Belarusian National Technical University, 2019
}

\begin{abstract}
The goal of this paper is to analyse the collected data on energy efficiency of electric vehicles from researches done by other authors and also to summarise all the factors affecting it. The majority of data available are obtained through simulations - therefore the emphasis in this paper will be placed on experimentally acquired data. The results of the analysis will be used for the planned e-bus eco-driving project for the purpose of Belgrade's public transportation system. Currently there are only 5 (ultracapacitor type) e-buses operating in Belgrade city public transport, which makes only $0.2 \%$ of all vehicles in rolling stock (making $16 \%$ together with other electric-powered vehicles - trams and trolleybuses), but there are plans to acquire new 80 electric buses. With the rise of the number of electric vehicles, appropriate training of drivers is gaining more and more importance, and the results of the presented analysis make the basis for such training. This will hopefully increase the range of the buses used and help save the energy spent by public transportation, thus giving a little contribution to global fight for cleaner planet.
\end{abstract}

Keywords: electric vehicles, energy efficiency, energy consumption, eco-driving, public transportation

For citation: Maljković M., Stamenković D., Blagojević I., Popović V. (2019) The Analysis of Available Data on Energy Efficiency of Electric Vehicles to be Used for Eco-Driving Project Development. Science and Technique. 18 (6), 504-508. https://doi.org/10.21122/2227-1031-7448-2019-18-6-504-508

\section{Анализ имеющихся данных по энергоэффективности электромобилей, которые будут использоваться для разработки проекта экологического вождения}

\author{
М. Малькович ${ }^{1)}$, Д. Стаменкович ${ }^{1)}$, И. Благоевич ${ }^{1)}$, В. Попович ${ }^{1)}$ \\ ${ }^{1)}$ Белградский университет (Белград, Республика Сербия)
}

Реферат. Целью работы является анализ собранных ранее разными исследователями данных об энергоэффективности электромобилей, а также обобщение всех факторов, влияющих на нее. Большая часть из них получена с помощью моделирования, поэтому особое внимание в этой статье уделяется экспериментально установленным характеристикам. Результаты анализа будут использованы в рамках запланированного проекта по применению экологичного электробуса в системе общественного транспорта Белграда, где в настоящее время функционируют только пять электробусов (ультраконденсаторного типа), что составляет всего $0,2 \%$ от числа всех транспортных средств подвижного состава (16\% вместе с другими электромобилями - трамваями и троллейбусами), но планируется приобрести 80 новых электробусов. С ростом количества электромобилей все большее значение приобретает соответствующая подготовка водителей, и результаты представленного анализа служат основой такой подготовки. Данный подход позволит расширить ассортимент используемых автобусов и сэкономить энергию, затрачиваемую общественным транспортом, что внесет определенный вклад в глобальную борьбу за чистую планету.

Ключевые слова: электромобиль, энергоэффективность, потребление энергии, эковождение, общественный транспорт

Для цитирования: Анализ имеющихся данных по энергоэффективности электромобилей, которые будут использоваться для разработки проекта экологического вождения / М. Малькович [и др.] // Наука и техника. 2019. Т. 18, № 6. C. 504-508. https://doi.org/10.21122/2227-1031-2019-18-6-504-508

\author{
Адрес для переписки \\ Благоевич Иван \\ Белградский университет \\ ул. Кральице Марие, 16, \\ 11120 , Белград 35, Республика Сербия \\ Тел.: +381 11 337-02-66 \\ iblagojevic@mas.bg.ac.rs
}

\author{
Address for correspondence \\ Blagojević Ivan \\ University of Belgrade \\ 16 Kraljice Marije str., \\ 11120, Belgrade 35, Republic of Serbia \\ Tel.: +381 11 337-02-66 \\ iblagojevic@mas.bg.ac.rs
}




\section{Introduction}

By looking at Tab. 1, it can be seen that currently there are only 5 electric (ultracapacitor type) buses operating in Belgrade public transportation system, with 80 new e-buses planned. It is expected that this trend will continue [1], so it is very important to take all the advantages of electric buses usage. In order to make it possible, a new ecodriving project is planned. As a preparation for this project, a research on energy efficiency of electric buses needs to be conducted. There are many factors affecting it [2], and this paper will try to summarise them.

Table 1

Belgrade public transportation system rolling stock

\begin{tabular}{|l|c|}
\hline Buses & 2000 \\
\hline Trolleybuses & 119 \\
\hline Electric buses & 5 (80 new planned) \\
\hline Trams & 247 \\
\hline Total & $2371(2451)$ \\
\hline
\end{tabular}

\section{The analysis}

Two hundred electric vehicles (3 models made in the same factory and sharing the same platform) were driven by 741 drivers travelling more than two million kilometres during two years to explore the effects of weather conditions, travel distance and vehicle speed on the energy consumption [3]. The results show that winter period increases the consumption by $34 \%$ compared to summer period, reducing the autonomy by $25 \%$. The outside temperature of $14{ }^{\circ} \mathrm{C}$ was found to be the most suitable.

The effects of ambient temperature and vehicle auxiliary loads (air conditioning, heating and ventilation) were investigated in another study [4], collecting data from 68 electric vehicles in Japan for one year period, showing that the temperature range of 21.8 to $25.2{ }^{\circ} \mathrm{C}$ is most favourable to energy efficiency of the vehicle. Another important conclusion is that about $10 \%$ of energy can be saved by minimising unreasonable auxiliary loads.

Technical Research Centre of Finland (VTT) conducted a research in their laboratory using different driving cycles (Tab. 2) [5].

The research showed that $23 /-20{ }^{\circ} \mathrm{C}$ temperature drop, with cabin heater turned off, will shorten the range by $20 \%$ (30\% in worst case).
The results for each cycle are shown in Tab. 3 . The use of $4.5 \mathrm{~kW}$ cabin heater can shorten the range for more than $50 \%$ in urban driving cycles and by approximately $20 \%$ on open road (Tab. 4 ).

Table 2

The main parameters of driving cycles used

\begin{tabular}{|l|c|c|c|c|c|}
\hline \multicolumn{1}{|c|}{ Cycle } & $\begin{array}{c}\text { Distance, } \\
\mathrm{km}\end{array}$ & $\begin{array}{c}\text { Fverage } \\
\text { speed, } \\
\mathrm{km} / \mathrm{h}\end{array}$ & $\begin{array}{c}\text { Maximum } \\
\text { speed, } \\
\mathrm{km} / \mathrm{h}\end{array}$ & $\begin{array}{c}\text { Stops } \\
\text { during } \\
\text { cycle }\end{array}$ & $\begin{array}{c}\text { Run } \\
\text { time, } \\
\mathrm{s}\end{array}$ \\
\hline EURO & 11.007 & 33.6 & 120 & 12 & 1180 \\
\hline ECE15 & 4.052 & 18.7 & 50 & 4 & 780 \\
\hline EUDC & 6.955 & 62.6 & 120 & 0 & 400 \\
\hline Helsinki city & 6.600 & 19.1 & 55 & 17 & 1360 \\
\hline Artemis urban & 4.488 & 17.6 & 58 & 19 & 993 \\
\hline Road, FIN & 24.800 & 81.3 & 120 & 1 & 1370 \\
\hline $\begin{array}{l}\text { Artemis road, } \\
\text { EV }\end{array}$ & 16.641 & 60.3 & 111 & 1 & 981 \\
\hline $\begin{array}{l}\text { Artemis mo- } \\
\text { torway, EV }\end{array}$ & 23.793 & 105.6 & 130 & 0 & 736 \\
\hline
\end{tabular}

Table 3

Estimated range for each driving cycle

\begin{tabular}{|l|c|c|c|}
\hline \multirow{2}{*}{ Cycle } & \multicolumn{2}{|c|}{ Estimated range } & Difference \\
\cline { 2 - 3 } & $\begin{array}{c}+23^{\circ} \mathrm{C}, \\
\mathrm{km}\end{array}$ & $\begin{array}{c}-20^{\circ} \mathrm{C}, \\
\mathrm{km}\end{array}$ & $\begin{array}{c}-23, \\
\%\end{array}$ \\
\hline EURO & 124 & 88 & -29 \\
\hline Helsinki city & 125 & 106 & -15 \\
\hline Artemis urban & 99 & 74 & -26 \\
\hline Road, FIN & 91 & 70 & -23 \\
\hline Artemis road, EV & 113 & 90 & -20 \\
\hline Artemis motorway, $\mathrm{EV}^{*}$ & 72 & 53 & -26 \\
\hline Average, all cycles & 100 & 79 & -21 \\
\hline
\end{tabular}

Table 4

The impact of cabin heater use for each driving cycle

\begin{tabular}{|l|c|c|c|c|}
\hline $\begin{array}{c}\text { At }-20{ }^{\circ} \mathrm{C}, 4.5 \mathrm{~kW} \\
\text { heater cycle }\end{array}$ & $\begin{array}{c}\text { Heater } \\
\text { energy, } \\
\mathrm{kW} \cdot \mathrm{h}\end{array}$ & $\begin{array}{c}\text { Total } \\
\text { energy, } \\
\mathrm{kW} \cdot \mathrm{h}\end{array}$ & $\begin{array}{c}\text { Estima- } \\
\text { ted range, } \\
\mathrm{km}\end{array}$ & $\begin{array}{c}\text { Relative } \\
\text { impast, } \\
\%\end{array}$ \\
\hline EURO & 0.134 & 0.334 & 53 & -40 \\
\hline Helsinki city & 0.236 & 0.402 & 44 & -59 \\
\hline Artemis urban & 0.256 & 0.494 & 36 & -52 \\
\hline Road, FIN & 0.055 & 0.307 & 57 & -18 \\
\hline Artemis road, EV & 0.075 & 0.270 & 65 & -28 \\
\hline Artemis motorway, $\mathrm{EV}^{*}$ & 0.043 & 0.371 & 47 & -11 \\
\hline
\end{tabular}

One research showed that the most economical average vehicle speed is between 45 and $56 \mathrm{~km} / \mathrm{h}$ (Fig. 1), and that electric vehicles are more energy efficient for longer trips [3].

In another research, converted electric vehicle was driven for five months in real-world conditions [6]. The results showed that electric vehicles are more efficient in urban driving conditions than 
on highway, owing it to lower speeds and more frequent recuperation. However, this advantage cannot be always used, because the regenerative braking is not in function when battery is in high state of charge or when battery temperature is high [7]. By comparing several electric vehicles in 16 different driving cycles [8], it was shown that in urban conditions, a vehicle with a higher weight can benefit more from regenerative braking.

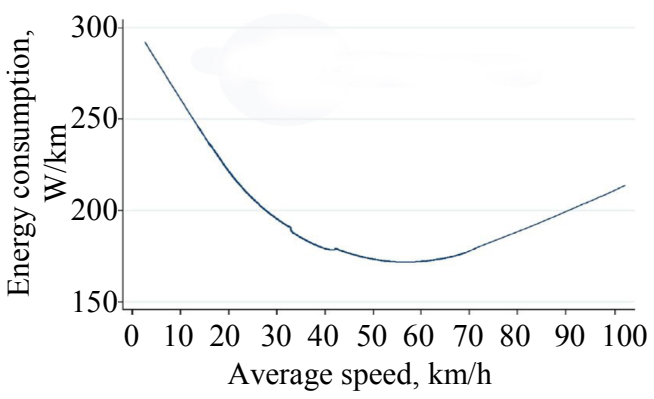

Fig. 1. The effect of average vehicle speed on the energy consumption

The results of another research [9] show that speed lower than $40 \mathrm{~km} / \mathrm{h}$ and ambient temperature about $20^{\circ} \mathrm{C}$ are optimal in terms of energy efficiency of electric vehicles. The researches founded that in some specific driving conditions auxiliary systems can reduce vehicle autonomy by $50 \%$. They also found that about $1 \%$ of energy is consumed by light and signalling devices.

Tab. 5 shows the impact of auxiliary systems on energy efficiency of electric vehicles [10] obtained by the Idaho National Laboratory. Again, cabin heater is identified as most influential, leaving air conditioning device closely behind.

Table 5

Impact of auxiliary systems on electric vehicle energy consumption

\begin{tabular}{|l|c|l|}
\hline \multicolumn{3}{|c|}{ Impact of equipment on EV performance } \\
\hline Accessory & $\begin{array}{c}\text { Range } \\
\text { impact }\end{array}$ & Comments \\
\hline Air conditioning & Up to 30\% & $\begin{array}{l}\text { Highly dependent on } \\
\text { ambient temperature } \\
\text { cabin temperature, and } \\
\text { air volume }\end{array}$ \\
\hline Heating & Up to 35\% & $\begin{array}{l}\text { Highly dependent on } \\
\text { ambient temperature and } \\
\text { cabin temperature }\end{array}$ \\
\cline { 1 - 1 } & & \\
Power steering & Up to 5\% & Depending on use \\
\hline Power brakes & & \\
\hline $\begin{array}{l}\text { Defroster } \\
\text { lights, stereo, phone, } \\
\text { power-assisted seats, } \\
\text { windows, locks }\end{array}$ & & \\
\hline
\end{tabular}

The research conducted in laboratory conditions on 3 different electric vehicles tested in few driving cycles in accordance with SAE J1634 showed that autonomy at $-7^{\circ} \mathrm{C}$ is reduced by approximately $20 \%$ in comparison with $20^{\circ} \mathrm{C}$, with cabin heater reducing it for additional $25 \%$. At $-20{ }^{\circ} \mathrm{C}$ the autonomy is reduced by $60 \%$ with cabin heater turned on [11].

A project [12] sponsored by the French Environment and Energy Management Agency and conducted with the help of few vehicle manufacturers also gave some conclusions on electric vehicle energy consumption influencing factors, based on simulation results, validated through certain driving cycles performed on chassis dynamometer. It is stated that auxiliary systems consume about $15-40 \%$ at average speed of $20 \mathrm{~km} / \mathrm{h}$ and $5-15 \%$ at average speed of $60 \mathrm{~km} / \mathrm{h}$. Regenerative braking also has a great (positive) influence on energy consumption with efficiency of about $50 \%$ at $20 \mathrm{~km} / \mathrm{h}$ and about $30 \%$ at $60 \mathrm{~km} / \mathrm{h}$. The study also showed that economical driver $\left(0.38 \mathrm{~m} / \mathrm{s}^{2}\right.$ mean acceleration) can save approximately $40 \%$ of energy at low speeds and $10 \%$ at high speeds, compared to aggressive driver $\left(1.03 \mathrm{~m} / \mathrm{s}^{2}\right.$ mean acceleration).

Researchers at the Aalto University performed simulations using several driving cycles (Tab. 6) in different operating conditions and for two different electric bus configurations, the first (EV1) with $77 \mathrm{~kW} \cdot \mathrm{h}$ battery and second (EV2) with $373 \mathrm{~kW} \cdot \mathrm{h}$ battery [13].

Table 6

Simulated driving cycles

\begin{tabular}{|l|c|c|c|c|c|c|}
\hline & BR & E11 & H550 & H3 & L51B & MAN \\
\hline Time, s & 1740 & 1548 & 3384 & 902 & 4283 & 1089 \\
\hline Distance, km & 10.9 & 10.2 & 28.7 & 10.3 & 16.1 & 3.3 \\
\hline Maximum speed, km/h & 58.2 & 58.4 & 74.9 & 71.7 & 59.0 & 40.5 \\
\hline $\begin{array}{l}\text { Average total speed, } \\
\text { km/h }\end{array}$ & 22.5 & 23.8 & 30.5 & 41.2 & 13.6 & 10.9 \\
\hline Average speed, km/h & 30.1 & 27.9 & 36.0 & 48.4 & 20.2 & 17.1 \\
\hline Stops per, km & 2.7 & 1.8 & 1.3 & 0.9 & 4.3 & 6.1 \\
\hline Aggressiveness, m/s ${ }^{2}$ & 0.235 & 0.152 & 0.206 & 0.195 & 0.281 & 0.306 \\
\hline $\begin{array}{l}\text { Climbing gradient, } \\
\text { m/km }\end{array}$ & 0.00 & 5.75 & 6.80 & 0.00 & 7.27 & 0.00 \\
\hline $\begin{array}{l}\text { Descending gradient, } \\
\text { m/km }\end{array}$ & 0.00 & -5.83 & -6.64 & 0.00 & -7.26 & 0.00 \\
\hline $\begin{array}{l}\text { Number of buses } \\
\text { in a fleet }\end{array}$ & 7 & 7 & 13 & 5 & 16 & 5 \\
\hline
\end{tabular}


Simulations were performed for vehicles loaded with half of passenger capacity and with constant power demand $(6 \mathrm{~kW})$ for auxiliary systems. Energy loss distribution for EV1 is shown in Fig. 2. It can be seen that main impacts on the energy consumption come from auxiliary systems, transmission and tyres. It can be seen that energy loss coming from rolling resistance is almost constant for all driving conditions. Aerodynamic drag also takes big part in energy loss at high speeds. Energy losses caused by auxiliary systems and in transmission are higher in driving cycles characterised by higher number of stops and lower average speed. The impact of vehicle weight due to passenger load is shown in Fig. 3. Again, this impact is more pronounced in driving cycles with lower average speed and higher number of stops. Fig. 4 shows the results of the same study and it shows that a higher aggressiveness increases the impact of passenger load on energy consumption in electric bus.

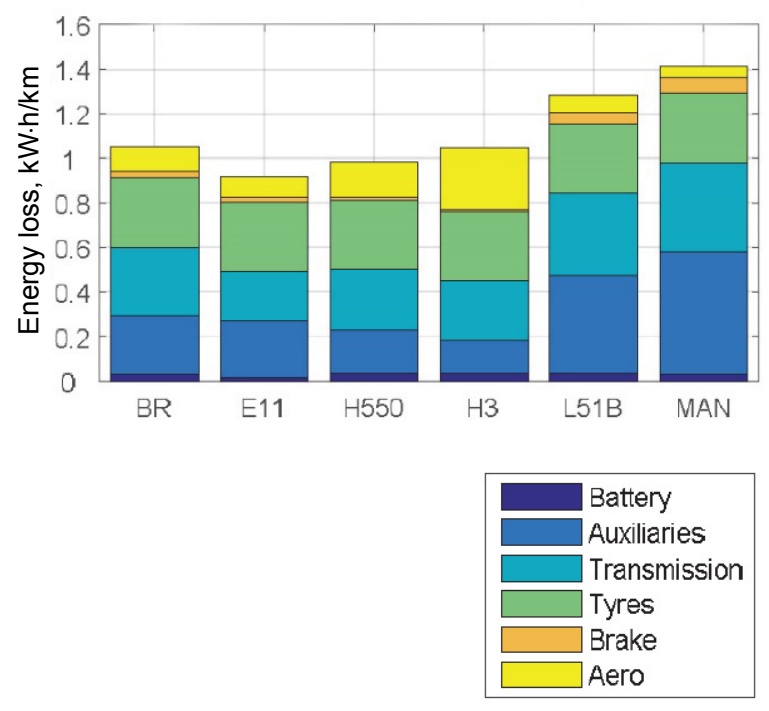

Fig. 2. EV1 energy loss distribution

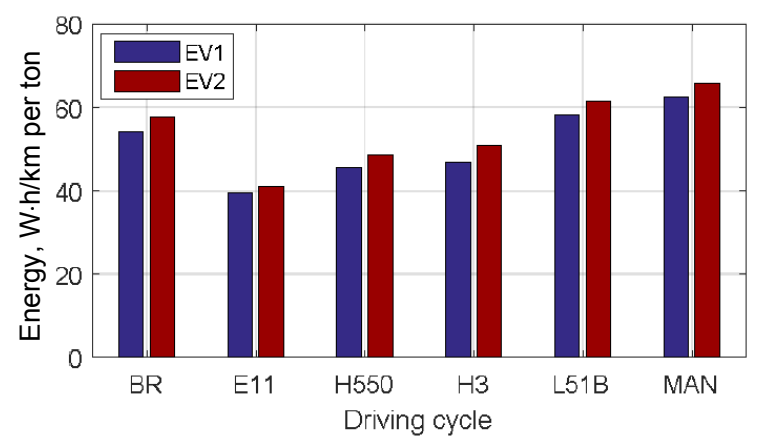

Fig. 3. Passenger load impact on energy consumption

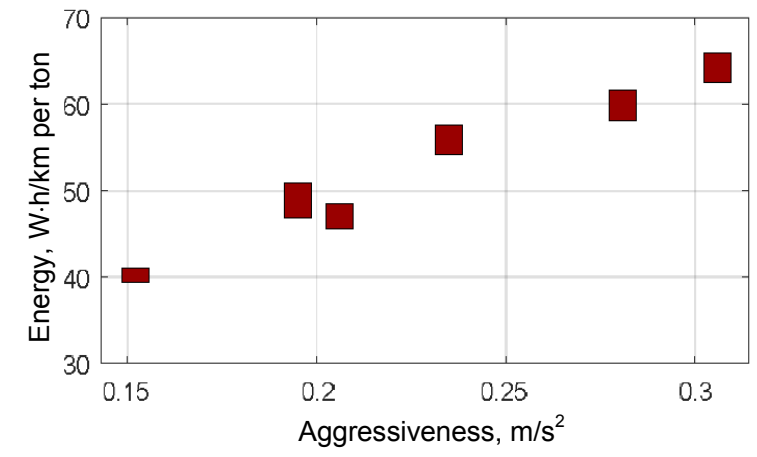

Fig. 4. Passenger load and driving aggressiveness combined

\section{CONCLUSIONS}

1. There are steps that can be taken in design process [14] to make vehicles more efficient. However, the authors found three main factors, not relating to the vehicle itself, affecting the energy efficiency of electric vehicles - ambient temperature (as a trigger for auxiliary loads), traffic conditions (urban vs. extra-urban) and driving style.

2. There is a little that can be done to lower the effects of ambient temperature. The fact that electric vehicles are more economical in city driving conditions, primarily due to the regenerative braking, is advantageous for public transportation. The biggest contribution to more efficient usage of electric vehicles can be made by changing the driving style, which is the goal of the future eco-driving project that will hopefully taught the drivers to avoid high speeds, accelerate moderately, drive in anticipatory manner, minimise the auxiliary loads (within the limits), use regenerative braking more often and coast whenever possible [15].

3. Future research will incorporate the realworld tests to confirm the findings and make the best possible input for the mentioned eco-driving project.

\section{ACKNOWLEDGEMENT}

This paper is a result of project financed by the Serbian Ministry of Education, Science and Technological Development (TR 35045 - "Scientific-Technological Support to Enhancing the Safety of Special Road and Rail Vehicles", project leader - Prof. Dr Vladimir Popović). 


\section{REFERENCES}

1. Blagojević A., Mitić S., Stamenković D., Popović V. (in press) (2019) The Future (and the Present) of Motor Vehicle Propulsion Systems. Thermal Science. https://doi.org/ 10.2298/TSCI 180307177B.

2. Maljković M., Blagojević I. Analysis of Various Impacts on Energy Consumption in Electric Vehicles. Proceedings of the YOUng Researchers Conference, 26 March 2019, Belgrade.

3. Fetene G. M., Kaplan S., Mabit S. L., Jensen A. F., Prato C. G. (2017) Harnessing Big Data for Estimating the Energy Consumption and Driving Range of Electric Vehicles. Transportation Research, Part D: Transport and Environment, 54, 1-11. https://doi.org/10.1016/j.trd.2017. 04.013.

4. Liu K., Wang J., Yamamoto T., Morikawa T. (2018) Exploring the Interactive Effects of Ambient Temperature and Vehicle Auxiliary Loads on Electric Vehicle Energy Consumption. Applied Energy, 227, 324-331. https://doi. org/10.1016/j.apenergy.2017.08.074.

5. Haakana A., Laurikko J., Granstörm R., Hagman R. (2013) Assesing Range and Performance of Electric Vehicles in Nordic Driving Conditions - End of Project Report. Nordic Energy Research. 40.

6. Wu X., Freese D., Cabrera A., Kitch W. A. (2015) Electric Vehicle's Energy Consumption Measurement and Estimation. Transportation Research, Part D: Transport and Environment, 34, 52-67. https://doi.org/10.1016/j.trd. 2014.10.007.

7. Varocky B. J. (2011) Benchmarking of Regenerative Braking for a Fully Electric Car. Report No D\&C 2011.002. TNO Automotive, Helmond\&Technische Universiteit Eindhoven.

8. Fiori C., Ahn K., Rakha H. A. (2016) Power-Based Electric Vehicle Energy Consumption Model: Model Development and Validation. Applied Energy, 168, 257-268. https://doi.org/10.1016/j.apenergy.2016.01.097.
9. Evtimov I., Ivanov R., Sapundjiev M. (2017) Energy Consumption of Auxiliary Systems of Electric Cars. MATEC Web of Conferences, 133, 06002. https://doi.org/10.1051/ matecconf $/ 201713306002$.

10. EV Auxiliary Systems Impacts, Idaho National Laboratory. Available at: https://avt.inl.gov/sites/default/files/pdf/ fsev/auxiliary.pdf.

11. Meyer N., Whittal I., Christenson M., Loiselle-Lapointe A. (2012) The Impact of Driving Cycle and Climate on Electrical Consumption \& Range of Fully Electric Passenger Vehicles. Proceedings of the EVS26 - the $26^{\text {th }}$ International Electric Vehicle Symposium, 6-9 May 2012, Los Angeles.

12. Badin F., Le Berr F., Briki H., Dabadie J.-C., Petit M., Magand S., Condemine E. (2013) Evaluation of EVs Energy Consumption Influencing Factors, Driving Conditions, Auxiliaries Use, Driver's Aggressiveness. 2013 World Electric Vehicle Symposium and Exhibition (EVS27). https://doi.org/10. 1109/evs.2013.6914723.

13. Lajunen A., Tammi K. (2019) Evaluation of Energy Consumption and Carbon Dioxide Emissions of Electric City Buses, Electric Commercial Vehicles (ECV) - Final Report. VTT Technology, (348), 104-120.

14. Gordić M., Stamenković D., Popović V., Muždeka S., Mićović A. (2017) Electric Vehicle Conversion: Optimisation of Parameters in the Design Process. Tehnicki Vjesnik - Technical Gazette, 24 (4), 1213-1219. https://doi.org/10. 17559/tv-20160613131757.

15. Neumann I., Franke T., Cocron P., Krems J. F., Bühler F. (2015) Eco-Driving Strategies in Battery Electric Vehicle Use - How do Drivers Adapt Over Time? IET Intelligent Transport Systems, 9 (7), 746-753. https://doi.org/10. 1049/iet-its.2014.0221.

Received: 08.10.2019

Accepted: 29.11.2019

Published online: 06.12.2019 